Studi Kelayakan Pembangunan Instalasi Jaringan Pipa Air Dengan Metode Cost \& Benefit Analysis

\title{
STUDI KELAYAKAN PEMBANGUNAN INSTALASI JARINGAN PIPA \\ AIR DENGAN METODE COST \& BENEFIT ANALYSIS GUNA \\ MEMINIMALKAN WAKTU MATERIAL HANDLING
}

\author{
Esa Rengganis \\ Prodi Teknik Industri \\ Sekolah Tinggi Teknologi Adisutjipto \\ Jalan Janti Blok R Lanud Adisutjipto, Yogyakarta \\ esarengganisstta@gmail.com
}

\begin{abstract}
Production facility have a significant influence on production process. CV Jokudo Kamsa got a problem on water filling on rotary drum, it takes 120 minutes on tanning process. It causes the facility is not enough for this process. So, we need to build pipe installation to reduce material handling time, especially on water filling's time.

Feasibility study on pipe installation based on Benefit Cost Analysis Methode. We applied NPV, Payback Period and Return On Investment.

Based on data tabulation we found Rp. 84,787,387,75 on NPV, 74,87 percent on ROI and 5.23 months on PP. And the most important thing we can reduce material handling time in 70 minutes on water filling with material handling cost as big as Rp. 139,804,9.
\end{abstract}

Keywords: material handling time, benefit cost analysis

Abstrak

Fasilitas produksi mempunyai pengaruh yang sangat besar dalam proses operasi. Permasalahan yang dihadapi pada CV. Jokudo Kamsa adalah proses pengisian air pada pengolahan kulit yang memerlukan waktu kurang lebih 120 menit. Hal ini disebabkan karena minimnya peralatan dan perlengkapan yang digunakan pada saat proses pengisian air pada tangki penyamakan. Sehingga perlu dilakukan pembangunan instalasi jaringan pipa air.

Studi kelayakan pembangunan instalasi jaringan pipa air dilakukan dengan menggunakan metode Benefit Cost Analysis. Pada analisis ini digunakan metode NPV, Payback Period dan Return On Investment.

Berdasarkan hasil penelitian didapatkan Nilai Net Present Value untuk proyek sebesar Rp. 84.787.387,75. Nilai Return On Investment sebesar 74,87 persen dan Payback Period selama 5,23 bulan. Berdasarkan metode Benefit Cost Analysis yang telah dilakukan proyek pembangunan instalasi jaringan pipa air layak untuk dilaksanakan. Terjadi penurunan waktu material handling selama 70 menit untuk satu kali proses pengisian air dari tangki penampungan ke tangki pengolahan dengan penurunan biaya material handling sebesar $\mathrm{R} p$. $139.804,9$.

Kata kunci: waktu material handling, benefit cost analysis 


\section{Pendahuluan}

CV. Jakudo Kamsa merupakan salah satu industri yang bergerak pada proses pengolahan kulit, dari bahan mentah sampai dengan produk setengah jadi yang menjadi input bagi perusahaan sepatu maupun tas yang menggunakan kulit sebagai bahan baku utama bagi produk-produk mereka.

Pada penelitian yang dilakukan sebelumnya, diketahui bahwa biaya material handling yang harus dikeluarkan sebesar Rp. 346.190,5. Kemudian setelah dilakukan re-layout terjadi penurunan biaya material handling sebesar Rp. 18.964,4 atau sebesar 5,47\%. Dari hasil pengamatan yang dilakukan diketahui bahwa terdapat proses persiapan produksi yang relatif lama, yaitu pada proses pengisian air ke tangki pengolahan kulit. Persiapan peralatan dan tenaga pengisian air memakan waktu kurang lebih 25 menit dan waktu pengisian air memakan waktu lebih dari 1 jam.

Melihat kondisi yang terjadi di lapangan, maka peneliti memutuskan untuk melakukan studi kelayakan pembangunan instalasi jaringan pipa air dalam rangka untuk meminimalkan waktu material handling. Metode yang digunakan adalah metode cost \& benefit analysis, di mana metode ini dapat mengidentifikasikan dan mengkonversi komponen-komponen penilaian, yang berupa biaya-biaya dan manfaat-manfaat kedalam nilai ekonomis.

\section{Tinjauan Pustaka}

\subsection{Tujuan Tata Letak Pabrik}

Perancangan tata letak pabrik sebagai perencanaan dan integrasi aliran komponenkomponen suatu produk untuk mendapatkan interelasi yang paling efektif dan efisien antar operator, peralatan, dan proses transformasi material dari bagian penerimaan sampai ke bagian pengiriman produk jadi.Perencanaan dan pengaturan tata letak pabrik memiliki tujuan untuk mengatur area kerja dan fasilitas produksi yang paling ekonomis dan efektif untuk meningkatkan produktivitas. Tata letak pabrik yang baik akan dapat memberikan keuntungan-keuntungan sebagai berikut:

a. Menaikkan output produksi.

b. Mengurangi waktu tunggu.

c. Mengurangi proses material handling.

d. Penghematan penggunaan area untuk produksi, gudang dan service.

e. Mengurangi inventory in-process.

f. Proses manufacturing yang lebih singkat. 
g. Mengurangi faktor yang bisa merugikan dan mempengaruhi kualitas dari bahan

h. Mengurangi kemacetan dan kesimpangsiuran.

Langkah-langkah yang diperlukan dalam perencanaan layout pabrik tersebut dapat diuraikan sebagai berikut :

a. Analisa produk.

b. Analisa proses.

c. Analisa data masa lalu dan analisa pasar.

d. Analisa macam dan jurnlah mesin atau equipment dan luas area yang dibutuhkan.

e. Pegembangan altematif tata letak.

f. Perancangan tata letak mesin dan departemen dalam pabrik.

\subsection{Prinsip Dasar Pemindahan bahan}

Dalam prinsip dasar sistem pemindahan bahan harus dipertimbangkan beberapa aturan dasar sebagai berikut:

- Pemindahan bahan yang tidak begitu penting sebaiknya dihindari.

- Penempatan mesin dan peralatan produksi lainnya direncanakan sedemikian rupa sehingga jarak antar operasi seminimal mungkin dan gerakan bolak-balik sebaiknya dihindari.

- Peralatan pemindahan bahan yang dibutuhkan dipilih secara efektif dan efisien.

- Peralatan pemindahan bahan yang dibutuhkan dipilih secara seksama dan cermat dari segi teknis maupun segi ekonomis.

- Bahan sebaiknya dipindahkan dalam volume, kuantitas, atau unit-unit yang kecil.

- Material sebisa mungkin dipindah melalui lintasan yang lurus dan pendek.

- Aktifitas-aktifitas pemindahan bahan sebisa mungkin dikelompokan, dikombinasi, dan dieliminasi.

- Sebaiknya operator yang berpindah dari pada material yang dipindahkan.

\subsection{Ongkos Material Handling}

Di dalam merancang tata letak pabrik, maka aktivitas pemindahan bahan merupakan salah satu hal yang cukup penting untuk diperhatikan dan diperhitungkan. Tujuan dari pemindahan bahan adalah sebagai berikut:

1. Menaikkan kapasitas.

2. Memperbaiki kondisi kerja.

3. Memperbaiki pelayanan pada pelanggan. 
4. Meningkatkan pemanfaatan ruang dan peralatan.

5. Mengurangi ongkos

Beberapa aktivitas material handling yang perlu diperhitungkan adalah pemindahan bahan menuju gudang bahan baku dan keluar dari gudang jadi serta pemindahan atau pengangkutan yang terjadi di dalam pabrik saja. Faktor - faktor yang mempengaruhi perhitungan ongkos material handling diantaranya adalah jarak tempuh dari satu stasiun kerja ke stasiun kerja yang lain dan ongkos pengangkutan per meter gerakan. Pengukuran jarak tempuh tersebut disesuaikan dengan kondisi yang ada di lapangan. Dengan demikian, jika jarak tempuh sudah ditentukan dan frekuensi material handling sudah diperhitungkan maka ongkos material handling dapat diketahui, di mana :

Total $\mathrm{OMH}=($ Ongkos per meter gerakan $) \times($ Jarak tempuh pengangkutan $) \times($ Frekuensi $)$

\subsection{CRAFT}

CRAFT (Computerized Relative Allocation of Facilities Techniques) bertujuan untuk meminimumkan biaya perpindahan material, di mana biaya perpindahan material didefinisikan sebagai aliran produk, jarak dan biaya unit pengangkutan. CRAFT awalnya dipresentasikan oleh Armour dan Bufa. CRAFT merupakan contoh program tipe teknik Heuristic yang berdasarkan pada interpretasi Quadratic Assignment dari program proses layout, yaitu mempunyai kriteria dasar yang digunakan meminimumkan biaya perpindahan material, dimana biaya ini digambarkan sebagai fungsi linier dari jarak perpindahan. Fungsi tujuan dari CRAFT adalah:

$$
\mathrm{F}=\max / \min \Sigma \text { ij Cij Wij Dij }
$$

di mana:

$\mathrm{Cij}=$ Ongkos aliran antar departemen

Wij= Frekuensi aliran antar departemen

Dij= Jarak antar departemen

\subsection{Metode Cost Benefit Analysis}

Cost Benefit Analysis atau analisis biaya manfaat adalah pendekatan untuk rekomendasi kebijakan yang memungkinkan analisis membandingkan dan menganjurkan suatu kebijakan dengan cara menghitung total biaya dalam bentuk uang dan total keuntungan dalam bentuk uang (Dunn, 2003).

Dalam melaksanakan Cost Benefit Analysis terdapat beberapa tahapan yang harus dilakukan. Tahapan-tahapan tersebut adalah sebagai berikut : 
Tahapan dasar dalam melakukan analisis biaya manfaat secara umum meliputi :

\section{a. Penetapan tujuan analisis dengan tepat.}

b. Penetapan perspektif yang dipergunakan (identifikasi pemangku kepentingan yang terlibat).

c. Mengidentifikasi biaya dan manfaat.

d. Menghitung, mengestimasi, menskalakan dan mengkuantifikasi biaya dan manfaat.

e. Memperhitungkan jangka waktu (discount factor).

f. Menguraikan keterbatasan dan asumsi.

Biaya dalam proyek digolongkan menjadi empat macam, yaitu biaya persiapan, biaya investasi, biaya operasional, dan biaya pemeliharaan dan perbaikan.

\section{Biaya Persiapan}

Biaya persiapan adalah biaya yang dikeluarkan sebelum proyek yang bersangkutan benar-benar dilaksanakan.

\section{Biaya Investasi atau Modal}

Biaya investasi adalah biaya tanah, biaya pembangunan termasuk instalasi, biaya perabotan, biaya peralatan (modal kerja).

\section{Biaya Operasional}

Biaya operasional masih dapat dibagi lagi menjadi biaya gaji untuk karyawan, biaya listrik, air dan telekomunikasi, biaya habis pakai, biaya kebersihan, dan sebagainya.

4. Biaya Pembaharuan atau Penggantian

Pada awal umur proyek biaya ini belum muncul tetapi setelah memasuki usia tertentu, biasanya pada bangunan mulai terjadi kerusakan- kerusakan yang memerlukan perbaikan. Tentu saja terjadinya kerusakan-kerusakan tersebut waktunya tidak menentu, sehingga jenis biaya ini sering dijadikan satu dengan biaya operasional. Selain itu, masih ada lagi biaya yang mencerminkan true values tetapi sulit dihitung dengan uang, seperti pencemaran udara, air, suara, rusaknya/tidak produktifnya lagi lahan. Manfaat yang akan terjadi pada suatu proyek dapat dibagi menjadi tiga yaitu manfaat langsung, manfaat tidak langsung dan manfaat terkait.

1. Manfaat Langsung

Manfaat langsung dapat berupa peningkatan output secara kualitatif dan kuantitatif akibat penggunaan alat-alat produksi yang lebih canggih, keterampilan yang lebih baik dan sebagainya.

2. Manfaat Tidak Langsung 
Manfaat tidak langsung adalah manfaat yang muncul di luar proyek, namun sebagai dampak adanya proyek. Manfaat ini dapat berupa meningkatnya pendapatan masyarakat disekitar lokasi proyek (sulit diukur)

3. Manfaat Terkait

Manfaat terkait yaitu keuntungan-keuntungan yang sulit dinyatakan dengan sejumlah uang, namun benar-benar dapat dirasakan, seperti keamanan dan kenyamanan. Dalam penelitian ini untuk penghitungan hanya didapat dari manfaat langsung dan sifatnya terbatas, karena tingkat kesulitan menilainya secara ekonomi. sebagainya.

Metode-metode untuk menganalisis manfaat dan biaya suatu proyek yaitu Metode Payback Period (PP), Metode Net Present Value (NPV), Internal Rate of Return (IRR), Return on Investment (ROI) dan perbandingan manfaat biaya (Benefit Cost Ratio). 


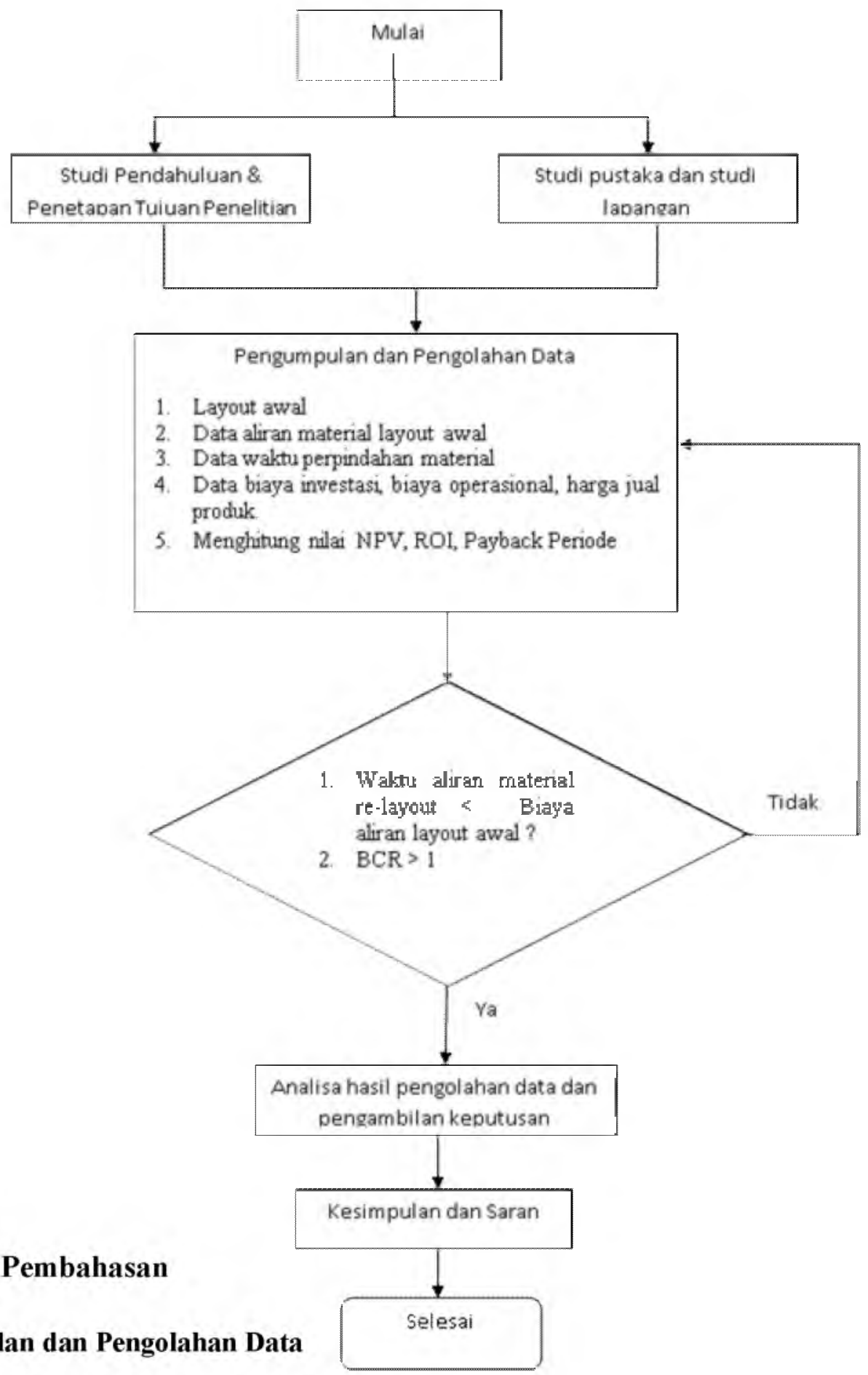

\subsubsection{Data Luasan Departemen}

Bagian produksi CV. Jakudo Kamsa terdiri dari 7 departemen. Luas tiap departemen dapat dilihat pada tabel 1 . 
Tabel1. Luas Departemen Pada Lantai Produksi

\begin{tabular}{|c|l|c|c|}
\hline No & \multicolumn{1}{|c|}{ Departemen } & Ukuran $(\mathrm{P} \times \mathrm{L})(\mathrm{m})$ & Luas $\left(\mathrm{m}^{2}\right)$ \\
\hline A & Pencucian & $4,05 \times 3,45$ & 13,97 \\
\hline B & Penyamakan & $4,05 \times 5,90$ & 15,79 \\
\hline C & Penghalusan & $4,90 \times 2,90$ & 14,21 \\
\hline D & Penjemuran & $6,00 \times 4,90$ & 29,40 \\
\hline E & Penimbangan & $1,50 \times 1,25$ & 1,875 \\
\hline F & Gudang Bahan Kimia & $4,00 \times 3,00$ & 12,00 \\
\hline G & Penyimpanan Air & $2,00 \times 1,75$ & 3,50 \\
\hline
\end{tabular}

\subsubsection{Mesin-mesin Produksi yang digunakan dan ukurannya}

Mesin - mesin dan peralatan yang digunakan dalam proses produksi dapat dilihat pada tabel 2 .

Tabel 2. Tabel Mesin dan Peralatan Produksi

\begin{tabular}{|l|c|c|c|c|}
\hline \multirow{2}{*}{$\begin{array}{c}\text { Nama } \\
\text { Mesin }\end{array}$} & \multicolumn{4}{|c|}{ Karakteristik Mesin } \\
\cline { 2 - 5 } & Jumlah & Panjang & Lebar & Diameter \\
\hline Rotary Drum & 3 & 3,55 & 2,45 & 1,8 \\
\hline Buffing & 5 & 0,63 & 0,58 & - \\
\hline Genset Kecil & 1 & 0.70 & 0.55 & - \\
\hline Timbangan & 1 & 0.80 & 0.50 & - \\
\hline Palang Kayu & 6 & 5,50 & 0.15 & - \\
\hline
\end{tabular}

\subsubsection{Jumlah Produksi}

Berdasarkan hasil pengamatan selama 3 bulan jumlah kulit yang disamak atau diproduksi rata-rata sebanyak 4200 sqft per bulan. Sehingga dalam jangka waktu 3 bulan jumlah kulit yang disamak kurang lebih $12600 \mathrm{sq} \mathrm{ft}$.

\subsubsection{Penentuan Frekuensi Perpindahan dan Jarak Perpindahan Stasiun Kerja}

Penentuan fekuensi perpindahan antar stasiun kerja adalah berapa jumlah satuan / unit yang dapat dipindahkan dalam sekali perpindahan serta perpindahan tersebut berapa kali dilakukan dalam satuan waktu (bulan). Data perpindahan bahan dapat dilihat seperti pada tabel 3 . 
Tabel 3. Tabel Frekuensi Material Handling

\begin{tabular}{|c|c|c|c|c|}
\hline From & To & Alat Angkut & $\begin{array}{c}\text { Kapasitas MH } \\
\text { (Unit) }\end{array}$ & Total MH \\
\hline A & B & Arco Sorong & $50 \mathrm{~kg}$ & 10 \\
\hline B & D & Arco Sorong & $50 \mathrm{~kg}$ & 10 \\
\hline B & E & Arco Sorong & $50 \mathrm{~kg}$ & 10 \\
\hline C & D & Selang & 100 liter & 15 \\
\hline C & E & Selang & 100 liter & 15 \\
\hline D & E & Arco Sorong & $50 \mathrm{~kg}$ & 5 \\
\hline E & F & Arco Sorong & $50 \mathrm{~kg}$ & 5 \\
\hline F & G & Arco Sorong & $50 \mathrm{~kg}$ & 10 \\
\hline F & H & Arco Sorong & $50 \mathrm{~kg}$ & 10 \\
\hline
\end{tabular}

\subsubsection{Biaya Material Handling Manual}

Ongkos material handling untuk setiap kali pengangkutan ditentukan berdasarkan ongkos per meter gerakan, dimana didalam ongkos tersebut sudah dipertimbangkan biaya pembelian dan depresiasi alat, serta biaya tenaga kerja.

a. Biaya pembelian dan depresiasi alat

Biaya pembelian dan depresiasi alat merupakan biaya yang dikeluarkan untuk membeli peralatan produksi dan depresiasi alat produksi selama jangka waktu umur ekonomis.

b. Biaya tenaga kerja

Biaya perpindahan yang dikerjakan oleh tenaga manusia didasarkan pada perhitungan waktu perpindahan yang dilakukan.

Biaya material handling secara rinci dapat dilihat pada tabel 4.

Tabel 4. Tabel Ongkos Material Handling

\begin{tabular}{|c|c|c|c|c|c|}
\hline From & To & OMH TK & OMH Alat & Dij x F & OMH / Meter \\
\hline A & B & 9424 & 16250 & 28,5 & 900,84 \\
\hline B & D & 14136 & 16250 & 130,25 & 233,29 \\
\hline B & E & 37696 & 16250 & 84 & 642,21 \\
\hline C & D & 37696 & 121,52 & 105,375 & 358,88 \\
\hline C & E & 23560 & 121,52 & 85,5 & 276,97 \\
\hline D & E & 37696 & 16250 & 23,625 & 2283,43 \\
\hline E & F & 28272 & 16250 & 55 & 809,50 \\
\hline F & G & 9424 & 16250 & 35,5 & 723,21 \\
\hline F & H & 14136 & 16250 & 107 & 283,98 \\
\hline
\end{tabular}




\subsubsection{Pembangunan Instalasi Jaringan Pipa Air}

\section{a. Procurement Cost}

Procurement Cost merupakan total semua pengadaan peralatan yang diinvestasikan untuk menunjang kegiatan bisnis. Biaya procurement ini dikeluarkan pada tahun pertama.

Tabel 5. Tabel Procurement Cost

\begin{tabular}{|c|l|c|}
\hline No & \multicolumn{1}{|c|}{ Jenis Biaya } & Jumlah \\
\hline 1 & Pembersihan tempat & Rp. $1,750,000$ \\
\hline 2 & Pekerjaan tanah & Rp. $1,950,000$ \\
\hline 3 & Sewa alat & Rp. $1,150,000$ \\
\hline & Total Procurement Cost & Rp. $4,850,000$ \\
\hline
\end{tabular}

b. Start Up Cost

Start Up Cost merupakan biaya yang harus dikeluarkan untuk mendukung kebutuhan operasional. Sama dengan procurement, start up cost biasanya dikeluarkan pada tahun-tahun pertama.

Tabel 6. Tabel Start Up Cost

\begin{tabular}{|c|l|c|}
\hline No & \multicolumn{1}{|c|}{ Jenis Biaya } & \multicolumn{2}{|c|}{ Jumlah } \\
\hline 1 & Pembelian Pipa & $\mathrm{Rp} \mathrm{2,973,000}$ \\
\hline 2 & Pengadaan Tangki Air & $\mathrm{Rp} 3,550,000$ \\
\hline 3 & Pembelian Pompa & $\mathrm{Rp} 3,509,000$ \\
\hline 4 & Instalasi Listrik & $\mathrm{Rp} . \quad 3,750,000$ \\
\hline 5 & Perlengkapan & $\mathrm{Rp} . \quad 1,450,000$ \\
\hline 6 & Biaya Instalasi Jaringan Air & $\mathrm{Rp} . \quad 2,700,000$ \\
\hline & Total Start Up Cost & $\mathrm{Rp} . \quad 17,932,000$ \\
\hline
\end{tabular}

\section{c. On Going Cost}

On Going Cost merupakan biaya-biaya yang harus dikeluarkan pada saat proyek telah dilaksanakan. Biaya ini terdiri dari biaya perawatan dan penggantian komponen atau spare part.

Tabel 7. Tabel On Going Cost

\begin{tabular}{|c|c|c|c|}
\hline No & Jenis Biaya & Tahun ke-1 & Tahun ke-2 \\
\hline 1 & Biaya Perawatan & Rp. $1,200,000$ & Rp. $1,400,000$ \\
\hline 2 & $\begin{array}{l}\text { Penggantian Spare } \\
\text { Part }\end{array}$ & - & $\begin{array}{ll}\text { Rp. } \quad 800,000 \\
\end{array}$ \\
\hline & Total On Going Cost & $1,200,000$ & Rp. $2,200.000$ \\
\hline
\end{tabular}




\subsubsection{Pengukuran Manfaat Tangibel dan Manfaat Intangibel}

Manfaat tangibel adalah manfaat berwujud yang secara faktual dapat dilihat pergerakannya melalui pendapatan yang diraih serta biaya yang dikeluarkan oleh perusahaan. Indikator dari keberhasilan/manfaat yang berdampak pada peningkatan pendapatan dan perluasan ke market yang baru.

Sedangkan manfaat intangibel adalah manfaat tidak berwujud tetapi dapat dirasakan, seperti peningkatan kepuasan konsumen, peningkatan kepuasan karyawan, peningkatan mutu perencanaan dan sebagainya.

Tabel 8. Tabel Manfaat Tangibel \& Intangible

\begin{tabular}{|c|l|r|r|r|}
\hline No & Manfaat & Thn ke-0 & Thn ke-1 & \multicolumn{2}{|c|}{ Thn ke-2 } \\
\hline 1. & Tangible & Rp. 0 & Rp. 12,000,000 & Rp. 18,000,000 \\
\hline 2. & Intangible & Rp. 0 & Rp. 6,000,000 & Rp. 9.000.000 \\
\hline 3. & Jumlah & Rp. 0 & Rp. 18,000,000 & Rp. 27,000,000 \\
\hline \multicolumn{3}{|c|}{ TOTAL Manfaat Tangible \& Intangible } & Rp. 45,000,000 \\
\hline
\end{tabular}

\subsubsection{Analisa Kelayakan}

Setelah proses perhitungan biaya-biaya dan manfaat dilakukan, maka dilakukan analisa kelayakan dengan menggunaan metode Net Present Value, metode Return On Investment dan metode Payback Periode. Secara ringkas perhitungan biaya-biaya dan pengukuran manfaat tangibel maupun intangibel dapat dilihat pada tabel berikut.

Tabel 9. Tabel Ringkasan Pengukuran Biaya

\begin{tabular}{|c|c|c|}
\hline No & Pengukuran & Jumlah \\
\hline 1. & Procurement Cost & Rp. $\quad 4,850,000$ \\
\hline 2. & Start Up Cost & Rp. $17,932,000$ \\
\hline 3. & On Going Cost & Rp. $3,400,000$ \\
\hline 4. & Manfaat Tangibel \& Intangibel & Rp. $45,000,000$ \\
\hline
\end{tabular}

a. Metode Net Present Value

Perhitungan NPV berfungsi untuk membandingkan keseluruhan pengeluaran dan penerimaan pada tingkat bunga tertentu pada setiap tahunnya.

Besarnya investasi yang dikeluarkan

$=$ Procurement Cost + Start Up Cost + On Going Cost

$=$ Rp. 4,850,000+Rp. 17,932,000+Rp. 3,400,000

$=$ Rp. 26,182,000

$\mathrm{NPV}=\mathrm{Ao}+\left(\mathrm{Al} /(1+\mathrm{r})^{\mathrm{i}}\right)$ 


$$
\begin{aligned}
& \text { NPV }=-R p \cdot 26,182,000+\frac{R p \cdot 60,000,000}{(1+0,12)^{1}}+\frac{R p \cdot 72,000,000}{(1+0,12)^{2}} \\
& N P V=\text { Rp. } 84,787,387,75
\end{aligned}
$$

Dikarenakan nilai NPV >0, maka proyek tersebut layak untuk dilaksanakan.

b. Metode Return on Investment

Metode pengembalian investasi ROI digunakan untuk mengukur presentase manfaat yang dihasilkan oleh suatu proyek dibandingkan dengan biaya yang dikeluarkan.

$$
\begin{aligned}
\mathrm{ROI} & =(\text { Laba Bersih Sesudah Pajak)/(Total Aktiva }) \times 100 \% \\
& =\frac{\text { Rp.45,000,000 }- \text { Rp. 26,182,000 }}{\operatorname{Rp} .26,182.000} \times 100 \% \\
& =71,87 \%
\end{aligned}
$$

\section{c. Metode Payback Period}

Penilaian proyek investasi menggunakan metode ini didasarkan pada lamanya investasi tersebut dapat tertutup dengan aliran-aliran kas masuk, dan faktor bunga tidak dimasukkan dalam perhitungan ini.

Payback Period $=($ investasi awal $) /($ arus kas $) \times 1$ tahun

$$
\begin{aligned}
& =\frac{\pi p \cdot 26,182,000}{R p \cdot 60,000,000} \times 12 \text { bulan } \\
& =5,23 \text { bulan }
\end{aligned}
$$

\subsection{Pembahasan}

Setelah dilakukan pengolahan data didapatkan nilai NPV sebesar Rp. 84,787,387,75, nilai ROI sebesar 74,87 \% dan Payback Period selama 5,23 bulan. Berdasarkan hasil pengolahan data data dapat dinyatakan bahwa proyek pembangunan instalasi jaringan pipa air layak untuk dilaksanakan.

Pada saat sebelum adanya instalasi jaringan air ini waktu material handling yang dibutuhkan adalah selama 225 menit untuk sekali proses dengan biaya sebesar Rp. $346,190,50$. Dengan adanya jaringan pipa ini waktu pengisian air dari satu tangki pengolahan ke tangki pengolahan yang lain berlangsung lebih cepat, yaitu kurang lebih 155 menit untu sekali proses dengan biaya sebesar Rp. 206,385,6 untuk sekali proses.

Hal ini disebabkan karena pengisian air dari tangki ke tangki dilakukan dengan menggunakan jaringan pipa yang dibangun. Sehingga pengisian berlangsung lebih cepat dan tidak memerlukan banyak tenaga kerja, seperti saat proses pengisian dengan cara manual. 
Tenaga kerja atau operator hanya perlu membuka kran untuk mengisi air dan menutup kran pada saat air telah mencapai ketinggian tertentu.

\section{Kesimpulan}

Berdasarkan penelitian dan hasil pengolahan data didapatkan hasil sebagai berikut :

1. Nilai Net Present Value untuk proyek pembangunan instalasi jaringan pipa sebesar Rp. 84,787,387,75. Nilai Return On Investment sebesar 74,87 \% dan Payback Period selama 5,23 bulan.

2. Berdasarkan metode Benefit Cost Analysis yang telah dilakukan proyek pembangunan instalasi jaringan pipa air layak untuk dilaksanakan.

3. Terjadi penurunan waktu material handling selama 70 menit untuk satu kali proses pengisian air dari tangki penampungan ke tangki pengolahan dengan penurunan biaya material handling sebesar Rp. 139,804,9. 
Esa Rengganis

Daftar Pustaka

Apple, James M, 1990, Tata Letak Pabrik dan Pemindahan Bahan, Edisi Ketiga, Institut Teknologi Bandung, Bandung.

Chang, Yih-Long, 2003, WinQSB Decision Support Software for MS/OM. John Wiley \& Sons, Inc.

Group Technology Dan Algoritma Blocplan Untuk Meminimasi Ongkos Material Handling”, Jurnal Teknologi, Volume 3 Nomor 1, IST AKPRIND, Yogyakarta.

Hadiguna, Rika Ampuh dan Setiawan, Heri, 2008, Tata Letak Pabrik, Andi Yogyakarta, Yogyakarta.

Heragu, S., 1997, Fasilities Design. PWS Publishing. Boston.

Kasmir dan Jakfar, 2003, Studi Kelayakan Bisnis, Penerbit Kencana, Jakarta.

Nurmianto, Eko, 2004, Ergonomi Konsep Dasar dan Aplikasinya, Guna Widya, Surabaya.

Pujawan, Nyoman, 2009, Ekonomi Teknik, Guna Widya, Surabaya.

Suliyanto, 2011, Studi Kelayakan Bisnis, Andi Publisher, Jakarta.

Susanto, Dwi, Tony, dkk, 2013, Studi Kelayakan Investasi Perluasan Jaringan TV. Kabel pada PT XYZ Dengan Metode Cost \& Benefit Analysis, Semnas Sistem Informasi Indonesia SESINDO.

Susetyo, Joko, Simanjuntak, Adelina, Risma, Ramos, Magno, João, 2010, Perancangan Ulang Tata Letak Fasilitas Produksi Dengan Pendekatan.

Sutalaksana, Iftikar Z, dkk, 2006, Teknik Perancangan Sistem Kerja, ITB, Bandung.

Wahyudi, Eko, Sri, 2010, Perancangan Ulang Tata Letak Fasilitas Produksi di CV. Dimas Rotan Gatak Sukoharjo.

Wignjosoebroto, Sritomo, 2003, Tata Letak Pabrik dan Pemindahan Bahan, Edisi Ketiga, ITS, Surabaya.

Yulaisia, Rikal, 2010, Perancangan Ulang Tata Letak Pabrik Pada UD KURNIA Di Kota Dumai (Studi Kasus: UD KURNLA), Dumai. 